\title{
PEMETAAN KARAKTERISTIK PERIODE ULANG CURAH HUJAN MAKSIMUM DI KOTA MANADO
}

\section{MAPPING OF THE CHARACTERISTICS OF MAXIMUM RAINFALL RETURN PERIOD IN MANADO CITY}

\author{
Muhammad Tahmid ${ }^{1}$, Yosevina Nugrahenny Nugroho ${ }^{2}$, Farida Indriani ${ }^{3}$ \\ 1,2,3Stasiun Klimatologi Minahasa Utara \\ *E-mail: mtahmid751@gmail.com
}

Naskah masuk: 17 Juni 2020, Naskah diperbaiki: 7 Juli 2020, Naskah diterima: 16 Juli 2020

\begin{abstract}
ABSTRAK
Curah hujan dengan intensitas yang tinggi atau ekstrem mempunyai banyak dampak pada berbagai sektor. Salah satu dampak yang disebabkan oleh curah hujan tersebut adalah ancaman potensi banjir yang bisa mengganggu kehidupan masyarakat hingga menimbulkan korban jiwa. Penelitian ini menggunakan data curah hujan harian maksimum tahunan dari stasiun BMKG (Badan Meteorologi, Klimatologi, dan Geofisika) dan pos hujan yang berada di Kota Manado, Provinsi Sulawesi Utara. Tujuan dari penelitian ini adalah untuk mengetahui sebaran potensi kejadian curah hujan maksimum tahunan yang terjadi pada setiap periode ulang 10, 20, 30, 40, dan 50 tahun di Kota Manado yang diharapkan bisa digunakan untuk referensi kajian awal penanggulangan bencana alam yang terjadi akibat intensitas curah hujan yang tinggi. Hasil dari pengolahan curah hujan harian maksimum tahunan dengan metode iwai kadoya menunjukkan bahwa pada umumnya nilai curah hujan di Kota Manado menunjukkan kenaikan pada setiap periode ulang $10,20,30,40$, dan 50 tahun dengan rentang nilai curah hujan $240 \mathrm{~mm} /$ hari hingga $520 \mathrm{~mm} /$ hari.Curah hujan terendah terjadi pada periode ulang 10 tahunan dengan kisaran 240 $\mathrm{mm} / \mathrm{hari}$ pada wilayah Kota Manado bagian Tengah, sedangkan curah hujan tertinggi terjadi pada periode ulang 50 tahunan dengan kisaran $520 \mathrm{~mm} /$ hari pada wilayah Kota Manado bagian Selatan.
\end{abstract}

Kata kunci: curah hujan maksimum, Iwai Kadoya, periode ulang

\section{ABSTRACT}

Rainfall with high or extreme intensity has many impacts on any sector. One of the impacts caused by the rainfall is the potential threat of flooding that can disrupt people's lives and cause casualties. This study uses annual maximum daily rainfall data from the BMKG (Meteorological, Climatological, and Geophysical Agency) Stations and rainfall posts located in Manado City, North Sulawesi Province. The purpose of this study is to discover the distribution of potential annual maximum rainfall events that occur in each return period of 10, 20, 30, 40, and 50 years in Manado City which is expected to be used as a reference for the initial study of natural disaster management that occurs due to high rainfall intensity. The results of the processing of annual maximum daily rainfall using the Iwai Kadoya's Method shows that in general, the rainfall intensity in Manado City shows an increase in each return period of 10, 20,30, 40, and 50 year, its surroundings is $240 \mathrm{~mm} /$ day until $520 \mathrm{~mm} /$ day. The minimum rainfall intensity occur in the return period of 10 year with a range of $240 \mathrm{~mm} /$ day in the Central part of Manado City area, while the maximum rainfall intensity occur in the return period of 50 year with a range of $520 \mathrm{~mm} /$ day in the southern part of the Manado City area.

Keywords: maximum rainfall, Iwai Kadoya, return period. 


\section{Pendahuluan}

Kepulauan maritim Indonesia yang berada di wilayah memiliki curah hujan tahunan yang tinggi, curah hujan semakin tinggi di daerah pegunungan. Curah hujan yang tinggi di wilayah tropis pada umumnya dihasilkan dari proses konveksi, pengaruh angin zonal dan meridional, serta pembentukan awan hujan panas. Kondisi tidak stabil terjadi jika udara yang naik lembab dan lapse rate udara lingkungannya berada antara lapse rate adiabatic keringdan lapse rate adiabatic jenuh. Jadi kestabilan udara ditentukan oleh kondisi kelembaban. Karena itu jumlah hujan tahunan, intensitas, durasi, frekuensi dan distribusinya terhadap ruang dan waktu sangat bervariasi [7,9]. Faktor topografi memiliki pengaruh yang sangat besar terhadap variasi hujan secara spasial, dengan adanya gunung yang berhadapan dengan sumber uap air seperti lautan juga akan meningkatkan curah hujan di wilayah pegunungan tersebut terutama pada bagian depan yang menghadap arah angin, karena pada wilayah tersebut uap air akan terangkat naik karena adanya gunung dan membentuk awan [1].

Kota Manado dengan luas wilayah tercatat 157,26 $\mathrm{Km}^{2}$ dialiri oleh sungai Tondano dengan panjang $39,9 \mathrm{Km}$ dimana bagian hilirnya sepanjang $\pm 7 \mathrm{Km}$ melewati Kota Manado bersama anak sungainya yakni sungai Tikala dengan panjang 23,6 km. Hal ini menyebabkan Kota Manado menjadi wilayah yang potensial diterjang bencana banjir ketika terjadi peristiwa cuaca ekstrem yang didukung dengan intensitas curah hujan lebat s.d. sangat lebat hingga mendukung adanya luapan air di sepanjang aliran sungai-sungai tersebut $[2,8,11]$.

Penanganan masalah banjir tidak terlepas dari tersedianya infrastruktur pengendali banjir seperti bendungan, bendung, jaringan irigasi, saluran drainase dan lain-lain. Dalam mendesain bangunan air pengendali banjir tersebut dibutuhkan informasi curah hujan maksimum dengan periode ulang tertentu. Besarnya curah hujan maksimum untuk setiap rancangan bangunan air tergantung pada usia penggunaan dan kapasitas tampung, sebagai contoh untuk bangunan waduk yang besar dibutuhkan informasi hujan maksimum dengan periode ulang yang besar dengan periode ulang 50, 100 tahunan. Sedangkan untuk saluran irigasi membutuhkan informasi curah hujan maksimum dengan periode ulang yang pendek dengan periode ulang antara 2, 5, 10 tahunan [1].
Curah hujan maksimum akan mengalami peningkatan dalam jangka waktu tertentu. Namun jika kondisi tersebut dilihat langsung dari data curah hujan maksimum, nilai peningkatannya tidak terlihat secara signifikan. Maka dari itu, diperlukan perhitungan periode ulang curah hujan untuk mengetahui besarnya nilai peningkatan curah hujan maksimum, selain itu hasil periode ulang curah hujan dapat digunakan untuk mengetahui rentang waktu pengulangan curah hujan dengan nilai maksimum di suatu daerah akan terjadi kembali $[3,4,6,11]$.

Periode ulang adalah laju suatu hidrologi dalam hal ini adalah data curah hujan mencapai harga tertentu. Beberapa metode untuk menghitung nilai periode ulang memang sering digunakan, salah satunya adalah penggunaan metode Iway Kadoya $[1,4,10]$. Dalam metode ini data curah hujan yang digunakan adalah data curah hujan maksimum setiap bulannya yang diambil dari data pengukuran curah hujan setiap hari. Dalam penelitian ini terdapat variabel bebas dan terikat. Variabel bebas dari penelitian ini adalah curah hujan maksimum setiap bulan, sedangkan variabel terikatnya adalah periode ulang curah hujan [4].

Posisi geografis stasiun pengamatan atau pos hujan yang berdekatan tidak menjamin daerahdaerah tersebut mendapatkan dampak yang sama dari suatu fenomena [5]. Maka dari itu, pada penelitian ini menggunakan beberapa data yang mempunyai rentang data pengamatan relatif panjang dari beberapa titik stasiun BMKG maupun pos hujan, yang nantinya hasil yang diperoleh diharapkan mampu merepresentasikan kondisi di wilayah Kota Manado secara umum.

Kondisi Kota Manado yang telah dilanda bencana hidrometeorologi dalam kurun waktu beberapa tahun terakhir menjadi dasar penelitian ini perlu dilakukan. Hal ini berkaitan untuk memperoleh informasi peluang terjadinya curah hujan maksimum hingga ekstrem di wilayah Kota Manado yang tidak terdapat data pos hujan yang mewakili karakteristik masingmasing wilayah melalui hasil dari pemetaan periode ulang curah hujan maksimum yang telah diinterpolasi.

Dengan melakukan analisis dan pemetaan periode ulang curah hujan maksimum di beberapa stasiun dan pos hujan yang mewakili karakteristik Kota Manado diharapkan dapat memperoleh hasil yang nantinya tidak hanya digunakan sebagai investasi pengetahuan bagi praktisi prakirawan, informasi bagi masyarakat, 
para akademisi, namun bisa digunakan juga sebagai salah satu bahan untuk menyusun kajian awal strategi mitigasi terkait penanggulangan bencana di wilayah Kota Manado dan sekitarnya.

\section{Metodologi Penelitian}

Data yang digunakan dalam penelitian ini adalah data curah hujan harian maksimum tahunan yang diperoleh dari data observasi stasiun BMKG dan pos hujan di wilayah penelitian yaitu Kota Manado. Jumlah ketersediaan data dari Stasiun Meteorologi Sam Ratulangi diperoleh dari tahun 1981-2019 (39 tahun), Stasiun Geofisika Winangun 19862019 (33 tahun), Stasiun Klimatologi Minahasa Utara 1973-2019 (45 tahun), pos hujan KP Pandu 1986-2019 (31 tahun, terjadi kekosongan data 2 tahun). Untuk penentuan besarnya curah hujan dengan periode ulang $\mathrm{T}$ tahun dihitung menggunakan metode Iwai Kadoya dengan menggunakan persamaan:

$$
\zeta=c \log \frac{x+b}{x_{0}+b}
$$

$\zeta$ merupakan faktor frekuensi, c adalah faktor iwai kadoya, log $\left(x_{0}+b\right)$ adalah harga rata-rata dari $\log \left(x_{i}+b\right)$ dengan $(i=1, \ldots . . n)$ dan dinyatakan dengan $\left(X_{0} ; \quad b, c\right.$ dan $\left.x_{0}\right)$ menggunakan pendekatan persamaan berikut ini:

a. Pendekatan Nilai $\left(\mathrm{x}_{\mathrm{o}}\right)$

$$
\log x_{0}=\frac{1}{n} \sum_{i=1}^{n} \log x i
$$

Xi merupakan nilai curah hujan maksimum rata-rata. Nilai b adalah konstanta pada metode ini dengan menggunakan nilai bi yang diperoleh dengan pendekatan berikut:

b. Pendekatan Nilai (b)

$$
\left.\begin{array}{l}
b=\frac{1}{m} \sum_{i=1}^{m} b i, \mathrm{~m} \geq \mathrm{n} / 10 \\
b i=\frac{\left(x_{s} \cdot x_{t}-x_{0}^{2}\right)}{2 x_{0}-\left(x_{s}+x_{t}\right)}
\end{array}\right\}
$$

c. Pendekatan Nilai $\left(x_{\circ}\right)$

Nilai $x_{\circ}$ merupakan nilai dari jumlah curah hujan maksimum ditambah dengan konstanta $b$ yang diperoleh melalui pendekatan:

$$
X_{0}=\log \left(X_{0}+b\right)
$$

$$
=1 / n \log (x i+b)
$$

d. Pendekatan Nilai (c)

Nilai c adalah faktor metode iwai kadoya yang diperoleh melalui pendekatan:

$$
\begin{aligned}
1 / c & =\sqrt{\frac{2}{n}-1 \sum_{i-1}^{n} n\left(\log \frac{x i+b}{x_{0}+b}\right)} \\
& =\sqrt{\frac{2 n}{n-1} \cdot \sqrt{\bar{X}^{2}-x_{0}{ }^{2}}} \\
\bar{X}^{2} & =1 / n \sum_{i=1}^{n}\left\{\log \left(x_{i}+b\right)\right\}^{2}
\end{aligned}
$$

Keterangan:

$x_{s}=$ nilai curah hujan harian dengan nomor urut $\mathrm{m}$ dari data yang terbesar

$x_{t}=$ nilai curah hujan harian dengan nomor urut $\mathrm{m}$ dari data yang terkecil

$n$ = banyaknya data

$x_{i}=$ harga curah hujan maksimum harian pada tahun ke i dimana $\mathrm{i}=1,2,3$. . dst.

Untuk $\mathrm{m} \sim \mathrm{n} / 10$

Jika konstanta dari persamaan-persamaan di atas telah diketahui, maka curah hujan yang mungkin (probable rainfall) yang sesuai dengan kemungkinan lebih sembarang (arbitrary excess probably) dapat dihitung dengan persamaan:

$$
\begin{gathered}
\log (x+b)=\log \left(x_{0}+b\right)+(1 / c) \xi \\
=x_{0}+1 / c \xi
\end{gathered}
$$

Setelah memperoleh nilai dari setiap masingmasing periode ulang curah hujan yang diinginkan, maka data akan diolah kembali melalui perangkat lunak sistem informasi geografis untuk mendapatkan hasil pemetaan sebaran curah hujan maksimum di Kota Manado pada setiap periode ulang.

\section{Hasil dan Pembahasan}

Berdasarkan pengolahan data curah hujan harian maksimum tahunan dari 3 stasiun BMKG dan 1 pos hujan diperoleh informasi frekuensi kejadian curah hujan maksimum dan pemetaan curah hujan maksimum untuk periode ulang 10 , $20,30,40$, dan 50 tahun yang telah tersaji pada tabel dan gambar berikut: 
Tabel 1. Frekuensi Kejadian Curah Hujan Maksimum di Setiap Stasiun/Pos Hujan

Stasiun/Pos Hujan Bulan Frekuensi

\begin{tabular}{lcc}
\hline KP Pandu & Jan & 10 \\
Stageof Winangun & Des/Jan & 8 \\
Staklim Minahasa Utara & Des/Jan & 12 \\
Stamet Sam Ratulangi & Jan & 12 \\
\hline
\end{tabular}

Pada umumnya sesuai dengan Tabel 1 di atas, Kota Manado mengalami curah hujan maksimum terbanyak pada bulan Desember dan Januari. Frekuensi kejadian tertinggi terjadi selama 12 kali pada Bulan Desember dan Januari yang diperoleh dari data curah hujan di dua lokasi, yaitu Stasiun Klimatologi Minahasa Utara dengan panjang data 45 tahun dimulai dari tahun 1973 hingga 2019. Lokasi kedua yang juga mempunyai frekuensi kejadian tertinggi sebanyak 12 kali pada Bulan Januari yaitu Stasiun Meteorologi Sam Ratulangi, dengan panjang data 39 tahun dimulai dari tahun 1981 hingga 2019. Sedangkan frekuensi kejadian terendah sebanyak 8 kali pada Bulan Desember dan Januari yaitu Stasiun Geofisika Winangun, dengan panjang data 33 tahun dimulai dari tahun 1986 hingga 2019.

Kondisi tersebut sesuai dengan tipe hujan monsunal di kota manado, artinya terdapat 1 puncak curah hujan yang terjadi antara bulan Desember dan Januari pada sebaran curah hujan bulanan yang terjadi sepanjang tahun.

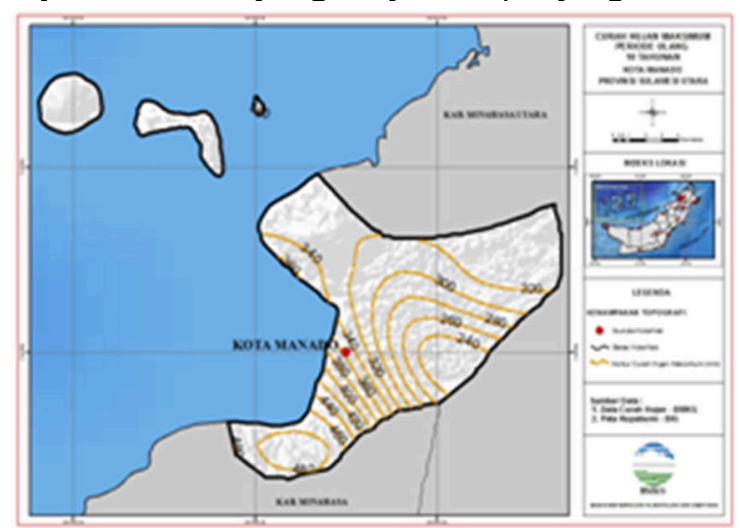

Gambar 1. Peta Curah Hujan Maksimum Periode Ulang 10 Tahunan di Kota Manado.

Hasil pemetaan curah hujan maksimum tahunan untuk periode ulang 10 tahunan menunjukkan bahwa secara umum di Kota Manado berpotensi terjadi curah hujan maksimum dengan intensitas lebih dari 200 $\mathrm{mm} /$ hari. Sesuai dengan hasil pemetaan yang tersaji pada Gambar 1, wilayah Kota Manado bagian Tenggara mempunyai potensi curah hujan maksimum tahunan senilai $240 \mathrm{~mm} / \mathrm{hari}$ dengan diikuti kenaikan nilai curah hujan ke sekitar wilayah Kota Manado. Pada wilayah Kota Manado bagian Utara, potensi kejadian curah hujan maksimum mencapai 300 hingga $340 \mathrm{~mm} / \mathrm{hari}$, sedangkan pada wilayah Kota Manado bagian Barat Daya mempunyai nilai tertinggi untuk potensi kejadian curah hujan maksimum sebesar $480 \mathrm{~mm} / \mathrm{hari}$. Hal ini turut memberikan informasi bahwa tidak hanya wilayah Barat Daya Kota Manado saja yang diharapkan waspada karena memiliki potensi nilai tertinggi curah hujan maksimum tahunan, tetapi seluruh wilayah dengan potensi curah hujan $>100 \mathrm{~mm} /$ hari yang masuk dalam kriteria hujan sangat lebat.

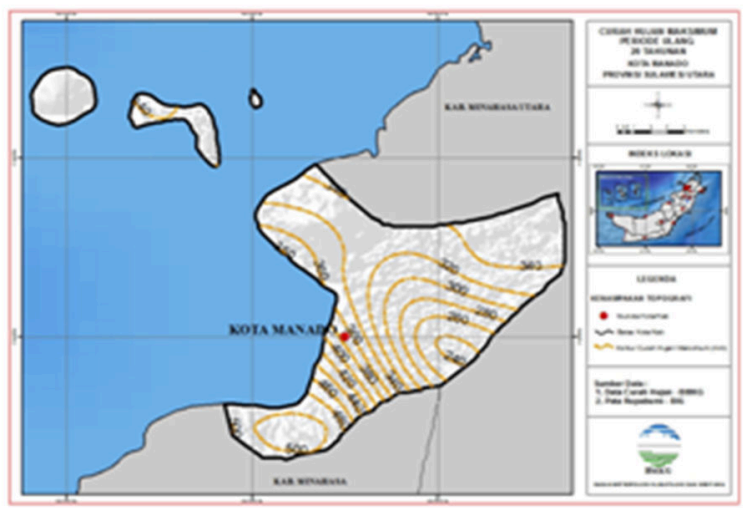

Gambar 2. Peta Curah Hujan Maksimum Periode Ulang 20 Tahunan di Kota Manado.

Hasil pemetaan curah hujan maksimum tahunan untuk periode ulang 20 tahunan menunjukkan bahwa secara umum di Kota Manado berpotensi terjadi curah hujan maksimum dengan intensitas lebih dari 200 $\mathrm{mm} /$ hari. Sesuai dengan hasil pemetaan yang tersaji pada Gambar 2, wilayah Kota Manado bagian tenggara mempunyai potensi curah hujan maksimum tahunan senilai $240 \mathrm{~mm} / \mathrm{hari}$ dengan diikuti kenaikan nilai curah hujan ke sekitar wilayah Kota Manado. Pada wilayah Kota Manado bagian Utara, potensi kejadian curah hujan maksimum mencapai 300 hingga $380 \mathrm{~mm} / \mathrm{hari}$, sedangkan pada wilayah Kota Manado bagian Barat Daya mempunyai nilai tertinggi untuk potensi kejadian curah hujan maksimum sebesar $500 \mathrm{~mm} / \mathrm{hari}$. Pada umumnya nilai curah hujan maksimum pada periode ulang 20 tahunan mempunyai nilai lebih tinggi dari periode ulang sebelumnya atau pada periode ulang 10 tahunan. 


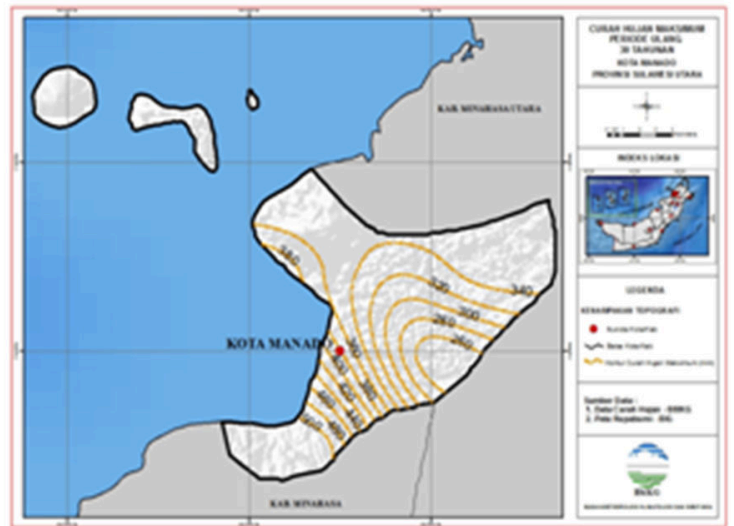

Gambar 3. Peta Curah Hujan Maksimum Periode Ulang 30 Tahunan di Kota Manado.

Sesuai dengan hasil pemetaan yang tersaji pada Gambar 3, curah hujan maksimum tahunan untuk periode ulang 30 tahunan menunjukkan bahwa secara umum di Kota Manado berpotensi terjadi curah hujan maksimum dengan intensitas lebih dari 200 $\mathrm{mm} / \mathrm{hari}$. Wilayah Kota Manado bagian Tenggara mempunyai potensi curah hujan maksimum tahunan senilai $260 \mathrm{~mm} /$ hari dengan diikuti kenaikan nilai curah hujan ke sekitar wilayah Kota Manado. Pada wilayah Kota Manado bagian Utara, potensi kejadian curah hujan maksimum mencapai 300 hingga 340 $\mathrm{mm} / \mathrm{hari}$, sedangkan pada wilayah Kota Manado bagian Barat Daya mempunyai nilai tertinggi untuk potensi kejadian curah hujan maksimum sebesar $500 \mathrm{~mm} / \mathrm{hari}$. Pada umumnya nilai curah hujan maksimum pada periode ulang 30 tahunan mempunyai nilai lebih tinggi dari periode ulang sebelumnya atau pada periode ulang 10 dan 20 tahunan.

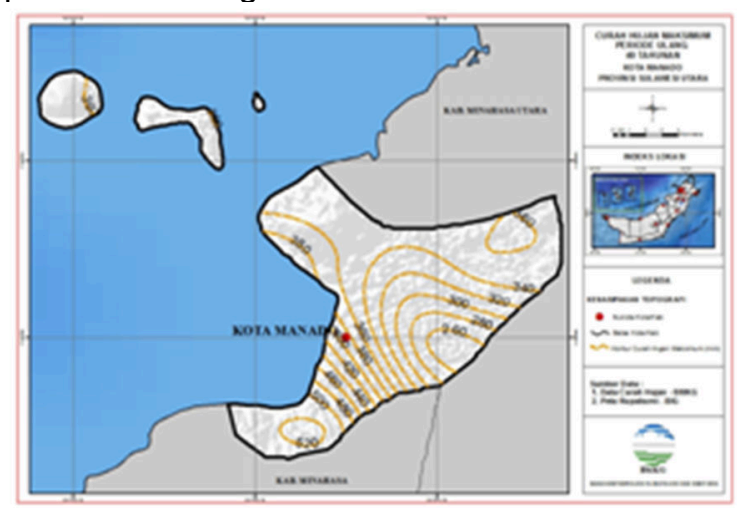

Gambar 4. Peta Curah Hujan Maksimum Periode Ulang 40 Tahunan di Kota Manado.

Berdasarkan hasil pemetaan yang tersaji pada Gambar 4, curah hujan maksimum tahunan untuk periode ulang 40 tahunan menunjukkan bahwa secara umum di Kota Manado berpotensi terjadi curah hujan maksimum dengan intensitas lebih dari $200 \mathrm{~mm} / \mathrm{hari}$. Wilayah Kota Manado bagian Tenggara mempunyai potensi curah hujan maksimum tahunan senilai $260 \mathrm{~mm} /$ hari dengan diikuti kenaikan nilai curah hujan ke sekitar wilayah Kota Manado. Pada wilayah Kota Manado bagian Utara, potensi kejadian curah hujan maksimum mencapai 300 hingga $380 \mathrm{~mm} / \mathrm{hari}$, sedangkan pada wilayah Kota Manado bagian Barat Daya mempunyai nilai tertinggi untuk potensi kejadian curah hujan maksimum sebesar $520 \mathrm{~mm} /$ hari. Pada umumnya nilai curah hujan maksimum pada periode ulang 40 tahunan mempunyai nilai lebih tinggi dari periode ulang sebelumnya atau pada periode ulang 10, 20, dan 30 tahunan.

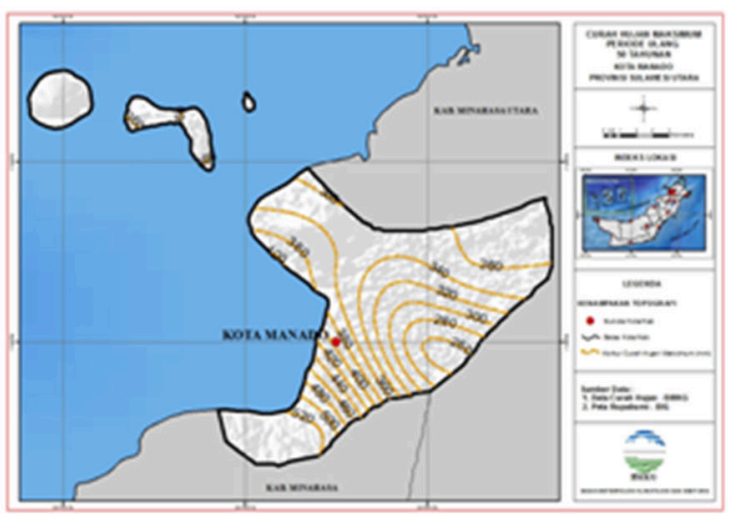

Gambar 5. Peta Curah Hujan Maksimum Periode Ulang 50 Tahunan di Kota Manado.

Hasil pemetaan curah hujan maksimum tahunan untuk periode ulang 50 tahunan menunjukkan bahwa secara umum di Kota Manado berpotensi terjadi curah hujan maksimum dengan intensitas lebih dari 200 $\mathrm{mm} /$ hari. Sesuai dengan hasil pemetaan yang tersaji pada Gambar 1, wilayah Kota Manado bagian Tenggara mempunyai potensi curah hujan maksimum tahunan senilai $260 \mathrm{~mm} / \mathrm{hari}$ dengan diikuti kenaikan nilai curah hujan sekitar wilayah Kota Manado. Pada wilayah Kota Manado bagian Utara, potensi kejadian curah hujan maksimum mencapai 300 hingga 400 $\mathrm{mm} /$ hari, sedangkan pada wilayah Kota Manado bagian Barat Daya mempunyai nilai tertinggi untuk potensi kejadian curah hujan maksimum sebesar $520 \mathrm{~mm} / \mathrm{hari}$. Pada umumnya nilai curah hujan maksimum pada periode ulang 50 tahunan mempunyai nilai lebih tinggi dari periode ulang sebelumnya atau pada periode ulang 10, 20, 30, dan 40 tahunan.

Berdasarkan hasil yang diperoleh dari analisis dan pemetaan periode ulang maksimum di Kota Manado, secara umum peluang peningkatan intensitas curah hujan maksimum terjadi pada setiap penambahan perulangan dari 10 tahunan hingga 50 tahunan [1,4]. Peningkatan intensitas tersebut terjadi tidak hanya pada satu titik 
wilayah saja, namun hampir di seluruh wilayah di Kota Manado. Hasil penghitungan periode ulang dengan metode Iway Kadoya mempunyai konsistensi dengan penelitian terkait sebelumnya, yang mana semakin bertambah periode ulang tahunannya maka diikuti dengan peningkatan peluang intensitas curah hujan yang akan terjadi.

Hasil dari pemetaan yang telah diinterpolasi pada wilayah Manado bagian Selatan dan Timur terdapat beberapa fakta yang menarik untuk dikaji lebih lanjut. Hal ini terkait adanya perbedaan sebaran intensitas curah hujan yang berasal dari titik lokasi pengambilan data curah hujan yang mempunyai jarak yang relatif berdekatan dibandingkan dengan yang lainnya, namun ternyata mempunyai karakteristik yang berbeda. Tidak hanya dipengaruhi oleh perbedaan topografi wilayah, tetapi juga didukung dengan kondisi dinamika atmosfer yang begitu dinamis dan fluktuatif [5]. Berbagai faktor yang berpengaruh diantaranya yaitu kondisi topografi, wilayah dataran tinggi mempunyai intensitas curah hujan yang relatif lebih tinggi dikarenakan adanya pengaruh angin lembah, angin gunung, dan variasi hujan orografis yang berperan dalam mendukung hal tersebut. Arah dan kecepatan angin juga diyakini membawa dampak bagi pergerakan awan hujan yang terdapat di atas wilayah Kota Manado. Sehingga wilayah yang mempunyai banyak tutupan awan di atasnya berpeluang lebih besar dalam proses terjadinya hujan. Tidak hanya itu, aktivitas angin darat dan angin laut juga turut berpengaruh dalam adanya perbedaan intensitas curah hujan maksimum yang terjadi diantara wilayah pesisir, dataran tinggi, dan dataran rendah.

Historis kejadian bencana alam banjir yang pernah melanda wilayah Kota Manado terjadi ketika curah hujan mencapai nilai maksimum atau ekstrem dibandingkan dengan normal bulanannya [11]. Pada hasil yang telah tersaji pada ulasan sebelumnya, potensi kejadian curah hujan maksimum terjadi saat memasuki bulan Desember dan Januari ketika mencapai puncak hujan pada tipe hujan monsunal. Namun perlu disadari bahwa tidak menutup kemungkinan bahwa nilai curah hujan maksimum akan terjadi di luar bulan-bulan tersebut. Seiring dengan kondisi dinamika atmosfer yang begitu dinamis dan fluktuatif, sehingga bisa saja menyebabkan terjadinya hujan ekstrem di kemudian hari.

\section{Kesimpulan}

Sesuai dengan hasil pengolahan dan pemetaan yang telah dijelaskan pada ulasan sebelumnya, secara umum potensi curah hujan maksimum tahunan pada setiap periode ulang 10, 20, 30, 40, dan 50 tahunan di Kota Manado mempunyai nilai $>200 \mathrm{~mm} /$ hari. Wilayah Manado bagian Tenggara pada periode ulang 10 tahunan mempunyai nilai terendah curah hujan maksimum sebesar $200 \mathrm{~mm} / \mathrm{hari}$, sedangkan nilai tertinggi terjadi ketika masuk dalam periode ulang 50 tahunan di wilayah Manado bagian Barat Daya sebesar 520 $\mathrm{mm} /$ hari. Berdasarkan analisis frekuensi kejadian intensitas curah hujan maksimum dan tipe hujan di Kota Manado, secara umum terjadi pada bulan Desember dan Januari yang merupakan puncak hujan pada wilayah yang mempunyai karakteristik tipe hujan monsunal.

\section{Daftar Pustaka}

[1] Basuki., Winarsih, I., \& Adhyani, N. L. (2009). Analisis Periode Ulang Hujan Maksimum Dengan Berbagai Metode. Agromet, 23(2), 76-92. https://doi.org/10.29244/j.agromet.23.2.7692

[2] Badan Meteorologi Klimatologi dan Geofisika. (2010). KEP.009 Tahun 2010 Tentang Prosedur Standar Operasional Pelaksanaan Peringatan Dini, Pelaporan dan Diseminasi Informasi Cuaca Ekstrim.

[3] Fauzi, M., Rinaldi.,\& Handayani, F. Y. (2012). Pemilihan distribusi frekuensi hujan harian maksimum tahunan pada wilayah sungai akuaman provinsi sumatera barat, 11(1), 18-24.

[4] Gara, M. N. I., Dwiridal, L., Nugroho, S. (2019). Analisis karakteristik periode ulang curah hujan dengan metode iwai kadoya untuk wilayah sumatera barat, Pillar of Physics, 12, 47-52.

[5] Gustari, I. (2007). Analisis Curah Hujan Pantai Barat Sumatera Bagian Utara Periode 1994-2007. Jurnal Meteorologi Dan Geofisika, 29-38.

[6] Nugroho, S. P. (2002). Evaluasi dan analisis curah hujan sebagai faktor penyebab bencana banjir jakarta. Jurnal Sains \& Teknologi Modifikasi Cuaca. 
[7] Pabalik, I., Ihsan, N., \& Arsyad, M. (2015). Analisis Fenomena Perubahan Iklim dan Karakteristik Curah Hujan Ekstrim di Kota Makassar. Jurnal Sains Dan Pendidikan Fisika, 11(1), 88-92.

[8] Sagita, N., \& Prasetya, R. (2013). Analisis Citra Satelit MTSAT dan TRMM menggunakan Software ER MAPPER, SATAID dan PANOPLY saat Kejadian Curah Hujan Ekstrim di Wilayah Manado, 16 Februari 2013. Jurnal Fisika Dan Aplikasinya, 9(2), 66.

[9] Sartika, L., Asrul, \& Nugroho, S. (2016). Analisis Hubungan Angin Zonal Dan Angin Meridional Lapisan 850 Milibar Terhadap Curah Hujan Di Sumatera Barat. Pillar of Physics, 49-56.

[10] Soehardi, F., \&Dinata, M. (2018). Recent analysis of maximum rain period. International Journal of Engineering and Technology (UAE).

[11] Sudamara, Y., Sompie, B., \& Mandagi, R. (2012). Optimasi Penanggulangan Bencana Banjir Di Kota Manado Dengan Metode Ahp (Analytical Hierarchy Process). Jurnal Ilmiah Media Engineering, 2(4) 